\title{
DYE SENSITIZED SOLAR CELLS (DSSC) DENGAN SENSITISER DYE ALAMI DAUN PANDAN, AKAR KUNYIT DAN BIJI BERAS MERAH (BLACK RICE)
}

\author{
Dahyunir Dahlan 1,", Tjiauw Siaw Leng ${ }^{1}$, Hermansyah Aziz ${ }^{2}$ \\ Jurusan Fisika, FMIPA - Universitas Andalas \\ Jurusan Kimia, FMIPA - Universitas Andalas \\ Kampus Limau Manis, Pauh, Padang 25163 \\ e-mail :Dahyunir@yahoo.com
}

\begin{abstract}
ABSTRAK
Dye alami dari daun pandan, akar kunyit dan biji black rice telah dipreparasi dalam larutan etanol sebagai sensitiser pada dye sensitized solar cells (DSSC). Dye campuran dipreparasi dengan perbandingan volume 1: 1 juga diteliti sebagai sensitiser pada DSSC. Metoda doctor blade dipakai untuk menumbuhkan lapisan tipis TiO2. Karakterisasi spektrofotometer UV-Vis dilakukan pada larutan dye untuk mengamati panjang gelombang yang diserap dye dan menghitung energi gap dye. Dari perhitungan diperoleh energi gap dye 1,387- 1,777 eV. Sedangkan dari karakterisasi arus tegangan $(\mathrm{I}-\mathrm{V})$, diperoleh efisiensi terbesar dye tunggal $0,056 \%$ dari dye kunyit dan efisiensi terbesar dye campuran $0,207 \%$ dari dye campuran black rice dan kunyit. Penggunaan dye campuran dapat meningkatkan performa dan efisiensi DSSC secara signifikan.
\end{abstract}

Kata Kunci : Dye, DSSC, sensitiser, doctor blade, TiO2, energi gap, efisiensi.

\begin{abstract}
ABSTRACK
Natural dye from pandanus leaves, turmeric root and black rice bean were prepared in a solution of ethanol as a sensitizer in dye sensitized solar cells (DSSC). Mixed dyes was prepared with a volumemetric ratio of 1: 1, they were was investigated as sensitizer in DSSC. The Doctor blade method is used to grow the thin film of TiO2. The characterization UV-Vis spectrophotomete a solution of dye to observe absorbance wavelength of dye and to calculate band gap of dye.According to the calculations, the band gap of dye on range 1,387-1,777 eV. While the characterization of the current-voltage (I-V), has obtained the largest efficiency of single dye from Curcumin is $0,056 \%$ and the largest efficiency of dye mixture from black rice and turmeric is 0,207 . The usage of dye mixture can improve performance dan efficiency of DSSC significantly.
\end{abstract}

Key Words : Dyes, DSSC, Senstizer, doctor blade, TiO2, Gap energy, efficiency.

\section{PENDAHULUAN}

Dye Sensitized Solar Cells (DSSC) merupakan solar sel generasi ke-3 yang ditemukan tahun 1991 oleh Michael Graetzel (O’regan dan Graetzel, 1991). DSSC menarik banyak perhatian kalangan akademis maupun industri karena menawarkan solusi energi terbarukan dengan tingkat polusi yang rendah, ramah lingkungan dan biaya produksi listrik yang murah (Lewis, dkk., 2005).

Sebuah DSSC terdiri atas fotoanoda dari kaca TCO (Tranparant Conductive Oxide) yang dilapisan semikonduktor berband gap tinggi seperti $\mathrm{TiO}_{2}, \mathrm{ZnO}, \mathrm{SnO}_{2}, \mathrm{Nb}_{2} \mathrm{O}_{5}$ (Graetzel, 2003) dan ditumbuhkan dengan berbagai metoda seperti doctor blade, screen printing (Maheswari dan Venkatachalam, 2013), elektroposisi, spin coating (Fahd, dkk., 2012),

JURNAL ILMU FISIKA (JIF), VOL 8 NO 1, MARET 2016 
tape casting, dip coating (Byung, dkk., 2013), liquid phase deposition (LPD), metal organic chemical vapour deposition (MOCVD) dan Mix-solvent-thermal method (Chunfeng, dkk, 2005). Elektroda lawan (counter electrode) adalah kaca TCO yang dilapisi logam platina atau karbon. Di antara kedua elektroda terdapat zat elektrolit yang berfungsi menjaga transpor elektron dapat tetap berlangsung.

DSSC dengan dye ruthenium sudah mencapai efisiensi yang tinggi, lebih dari $13 \%$ (Simon, dkk., 2014). Kelemahan DSSC dengan dye jenis ruthenium adalah jumlahnya sedikit di alam dan tidak ramah lingkungan karena beracun, sehingga menjadi pertimbangan untuk diaplikasikan pada DSSC dalam skala besar. Dye yang ramah lingkungan dan melimpah di alam, seperti dye dari bagian daun, biji, buah, batang dan akar tanaman menjadi pilihan alternatif sebagai sensitiser pada DSSC (Kimpa, dkk., 2012). Zat-zat seperti klorofil, betakaroten, antosianin, tanin, kurkumin, dan sebagainya pada tumbuhan dapat diaplikasikan sebagai sensitiser.

Pada tulisan ini, dye alami yang berasal dari daun pandan, akar kunyit dan biji black rice dipreparasi sebagai sensitiser pada DSSC. Dye kemudian dikarakterisasi dengan spektrofotometer UV-Vis untuk mengukur panjang gelombang yang diserap dan menghitung besar energi gap dye.

\section{METODA}

Adapun langkah-langkah yang dilakukan pada penelitian ini meliputi:

\subsection{Preparasi Dye Alami sebagai Sensitiser DSSC.}

Dye atau zat warna diperoleh dari daun pandan, akar kunyit dan biji black rice yang diekstrat dalam larutan etanol $(\mathrm{C} 2 \mathrm{H} 5 \mathrm{OH})$. Langkah-langkah preparasi meliputi pemilihan bahan, pembersihan, pencampuran. Material yang sudah kering kemudian digerus dengan mortar sampai halus pada ruang gelap, kemudian ditimbang 10 gram, dicampur $50 \mathrm{ml}$ etanol (Zhou, dkk., 2011) dan dibiarkan selama 2-3 jam dalam wadah gelap. Campuran kemudian disaring dengan kertas saring dan hasil saringan disimpan dalam wadah gelap tertutup dan siap digunakan sebagai sensitiser pada DSSC. Dye campuran dipreparasi dengan cara mencampurkan dua jenis dye dengan perbandingan volume 1:1 (Cho, dkk., 2012).

\subsection{Preparasi DSSC}

Preparasi DSSC meliputi perbersihan kaca ITO (Indiun Tin Oxide) beresintensi 15-30 $\mathrm{ohm} / \mathrm{cm} 2$ dengan ultrasonic cleaner dalam aquabides dan etanol selama masing-masing 10 menit. Lapisan tipis berasal dari serbuk TiO2 (P-25 Degussa) yang ditimbang sebanyak 0,5 gram dicampur dengan $1 \mathrm{ml}$ larutan asam nitrat (HNO3) 0,1 $\mathrm{M}$ dan 0,2 gram polietilen glikol (PEG-6000) (Valiulis dan Silickas, 2007) dan diaduk dengan magnetik stirrer selama 1 jam. Campuran sol gel yang terbentuk dideposisikan pada kaca ITO dengan teknik doctor blade menggunakan bantuan sendok stainless. Lapisan tipis kemudian disinter pada suhu 200 OC selama 30 menit dalam furnace. Lapisan tipis kemudian dikeluarkan dari furnace dan dicelupkan dalam larutan dye selama 2 jam. Lapisan tipis $\mathrm{TiO} 2$ yang telah tersensitasi dye alami dikeluarkan dan dibersihkan dengan etanol dan siap digunakan sebagai fotoanoda pada DSSC.

Elektroda lawan dipreparasi menggunakan grafit lunak yang berasal dari pensil 8B yang digoreskan pada kaca ITO dan dibakar dalam lilin menyala. Sedangkan larutan elektrolit ion I-/I3- dipreparasi dari campuran 0,5 M KI (kalium iodida) dan 0,05 M larutan I2 (iodine) dalam pelarut asetonitril (CH3CN) (Dahlan dan Fahyuan, 2014). Fotoanoda dan 
elektroda lawan kemudian disandwich dan zat elektrolit diinjeksikan diantara kedua elektroda.

\subsection{Karakterisasi DSSC}

Karakterisasi DSSC meliputi pengukuran absorbansi dan panjang gelombang cahaya tampak yang diserap dye dengan spektrofotometer UV-Vis. Dari grafik hasil pengukuran spektrofotometer UV-Vis, energi gap dye dihitung dengan metoda Tauch Plot. Sedangkan pada elektroda yang telah disandwich, karakterisasi I-V dilakukan dengan alat test I-V sederhana seperti pada Gambar 1.

\section{HASIL DAN DISKUSI}

\subsection{Absorbansi dan Energi Gap Dye alami}

Hasil pengukuran dengan spektrofotometer UV-Vis telihat pada Grafik 2. (a), (b). Dari Grafik 2, panjang gelombang yang diserap dye dalam rentang 400-700 nm, sehingga dye dapat digunakan sebagai sensitiser pada DSSC karena dapat menyerap energi cahaya tampak.

Dengan metoda Tauch Plot, energi gap dye tunggal dan campurannya dapat ditentukan. Persamaan yang digunakan adalah: $(\alpha h v)^{2}=C\left(h v-E_{g}\right)$, dengan $\alpha$ sebagai koefisien absorbansi, $C$ adalah sebuah konstanta, $h v$ sebagai energi foton dan $E_{g}$ adalah energi gap. Hasil perhitungan energi gap dye dapat dilihat pada Tabel 1.

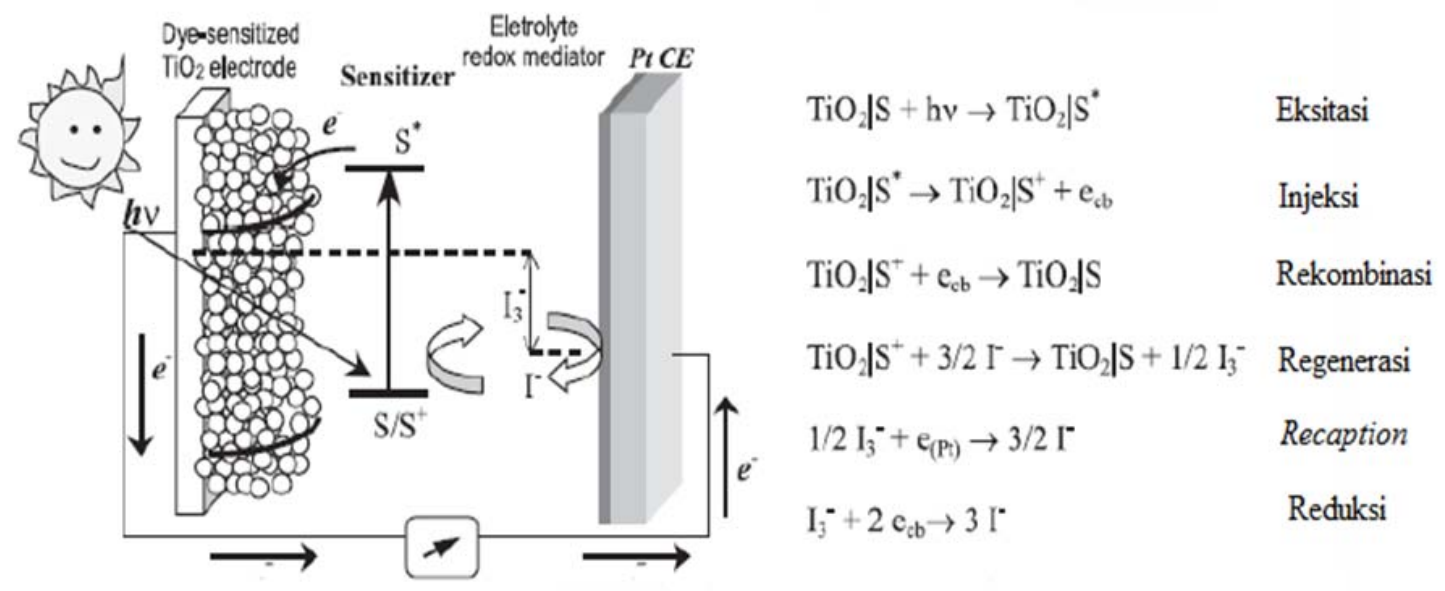

Gambar 1. Skema Representasi DSSC dan reaksi yang terjadi pada DSSC

(Sumber : Barnoy, dkk., 2011) 


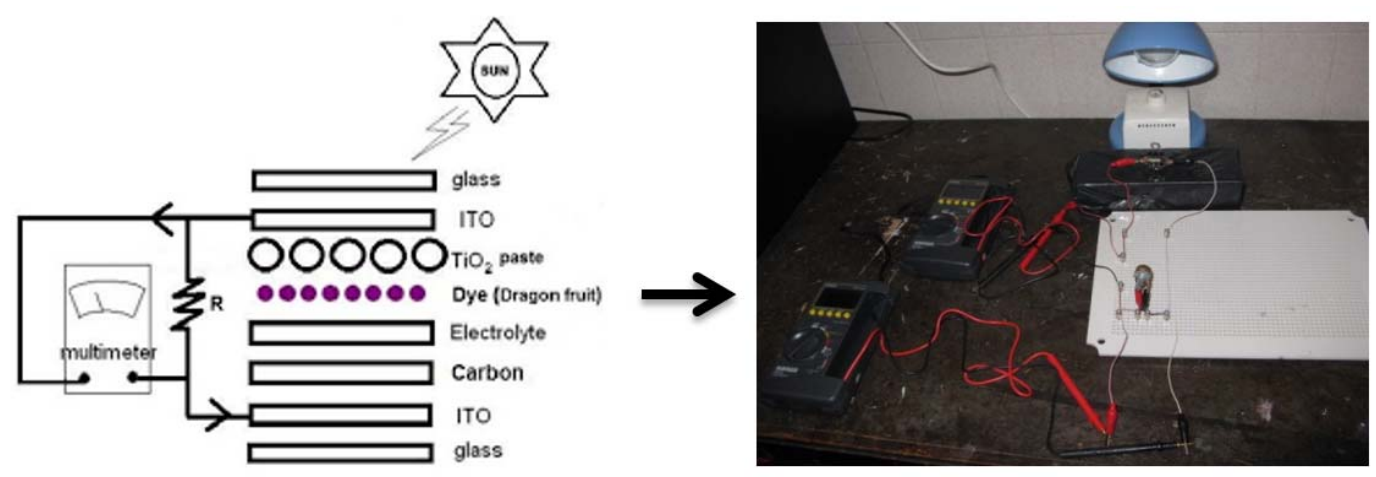

Gambar 2. Alat Test I-V sederhana

(sumber: Dahlan dan Fahyuan, 2014)

Tabel 1. Data energi gap dye, arus short circuit $\left(\mathrm{I}_{\mathrm{sc}}\right)$ dan tegangan open circuit $\left(\mathrm{v}_{\mathrm{oc}}\right)$ DSSC

\begin{tabular}{|c|c|c|c|c|c|}
\hline No. & Jenis Dye & Energi Gap $(\mathbf{e V})$ & $\mathbf{I}_{\text {sc }}(\boldsymbol{\mu A} \mathbf{A})$ & $\mathbf{V}_{\mathbf{o c}}(\mathbf{m V})$ & $\boldsymbol{\eta}(\mathbf{\%})$ \\
\hline 1. & Pandan & 1,387 & 18 & 685 & 0,055 \\
\hline 2. & Black rice & 1,524 & 42 & 610 & 0,053 \\
\hline 3. & Kunyit & 1,756 & 25 & 598 & 0,056 \\
\hline 4. & Black rice + pandan & 1,777 & 50 & 613 & 0,083 \\
\hline 5. & Kunyit + pandan & 1,756 & 36 & 499 & 0,085 \\
\hline 6. & Black rice + kunyit & 1,615 & 150 & 595 & 0,207 \\
\hline
\end{tabular}



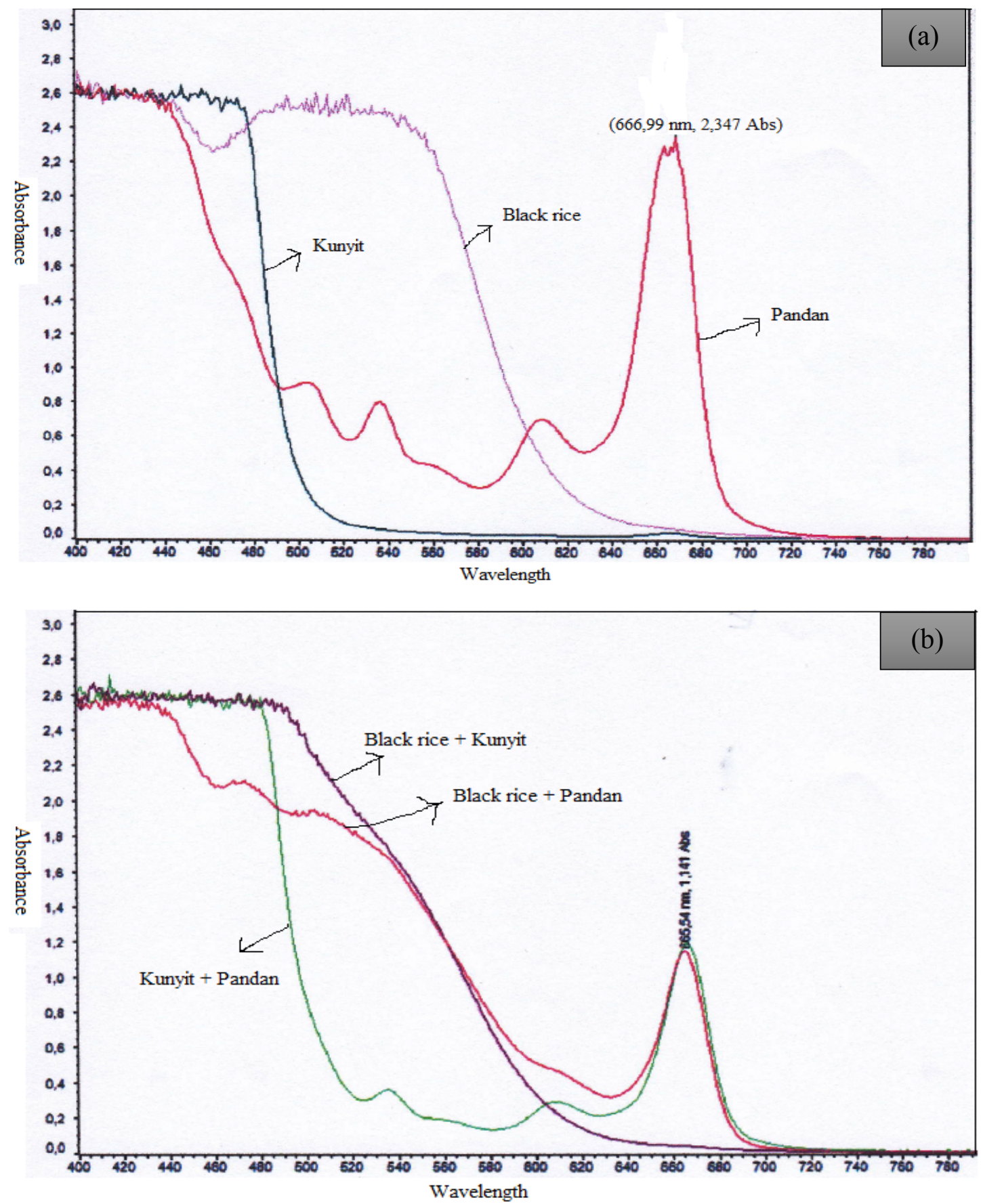

Gambar 3. Grafik hasil UV-Vis Dye : (a) pandan, black rice, kunyit

(b) black rice + pandan, kunyit + Pandan, black rice + kunyit

Dari Tabel 1. Terlihat energi gap dye tunggal dan campuran bernilai 1,387-1,777 eV Energi gap semikonduktor $\mathrm{TiO} 2$ dalam fase anatase sekitar $3,2 \mathrm{eV}$, artinya dye yang dipreparasi dapat digunakan sebagai sensitiser pada DSSC, karena nilai energi gap dye harus lebih kecil dari energi gap semikonduktor yang digunakan. Hal ini dikarenakan pada DSSC terjadi separasi muatan, di mana saat menyerap energi foton dari cahaya 
tampak, elektron pada dye akan tereksitasi dari keadaan HOMO (highest occupied molecular orbital) ke daerah LUMO (lowest unoccupied molecular orbital) yang selanjutnya elektron akan ditransfer ke pita konduksi semikonduktor $\mathrm{TiO}_{2}$. Energi gap dye menunjukkan lebar energi dari keadaan HOMO ke LUMO. Pada DSSC, lapisan tipis semikonduktor $\mathrm{TiO}_{2}$ berlaku sebagai semikonduktor tipe-n, sedangkan dye berlaku sebagai semikonduktor tipe-p.

\subsection{Fotoelektrokimia DSSC}

Karakterisasi arus tegangan (I-V) DSSC yang telah disandwich menggunakan alat test I-V sederhana, seperti terlihat pada Gambar 1 dan hasil karakterisasi ditunjukkan pada Tabel 1. Dari Tabel 1, arus short circuit yang terukur dari dye tunggal adalah 18-42 $\mu \mathrm{A}$, sedangkan tegangan open circuit 598-685 mV. Pada dye campuran arus short circuit yang terukur adalah $36-150 \mu \mathrm{A}$ dan tegangan open circuit $499-613 \mathrm{mV}$.

Perhitungan efisiensi DSSC dapat dilakukan dengan rumus: $\eta=\left(P_{m} / P_{i n}\right) 100 \%$, dimana $P_{m}=J_{m} v_{m}$, dengan $v_{m}$ adalah tegangan yang memberikan nilai daya maksimum, $J_{m}$ adalah rapat arus yang memberikan nilai daya maksimum, dalam mA.cm ${ }^{-2} . P_{\text {in }}$ adalah daya masukan sumber cahaya yang digunakan, diukur dalam $\mathrm{mW} \cdot \mathrm{cm}^{-2}$. Hasil perhitungan efisiensi DSSC yang disandwich selanjutnya ditunjukkan pada Tabel 1.

Dari data terlihat penggunaan dye campuran meningkatkan efisiensi DSSC, khususnya dye campuran black rice dan kunyit, dimana efisiensi meningkat secara signifikan dari 0,056\% menjadi $0,207 \%$, sedangkan penggunaan dye campuran black rice-pandan dan dye campuran kunyit-pandan efisiensi juga meningkat dibanding efisiensi dye tunggal. Pemakaian dye campuran membuat sinergi antara dua jenis dye, dimana panjang gelombang cahaya tampak yang diserap lebih lebar, sehingga lebih banyak energi cahaya tampak yang dikonversi menjadi energi listrik. Hal ini meningkatkan performa dan efisiensi DSSC.

\section{KESIMPULAN}

Dye alami yang berasal dari daun pandan, akar kunyit dan biji black rice dapat digunakan sebagai sensitiser pada DSSC. Daun pandan dengan dye klorofil, akar kunyit dengan dye kurkumin dan biji black rice dengan dye antosianin berpotensi sebagai dye alternatif yang ramah lingkungan.

Arus short circuit terbesar dari dye tunggal berasal dari dye black rice, besarnya 42 $\mu \mathrm{A}$, sedangkan dari dye campuran arus short circuit terbesar berasal dari dye campuran black rice dan kunyit yaitu $150 \mu \mathrm{A}$. Sedangkan tegangan open circuit terbesar dye tunggal berasal dari pandan yang besarnya $685 \mathrm{mV}$ dan untuk dye campuran berasal dari dye black rice dan pandan yaitu $613 \mathrm{mV}$.

Efisiensi tertinggi berasal dari dye black rice dan kunyit, yaitu 0,207\%, dibandingkan efisiensi tertinggi dari dye tunggal yang besarnya $0,056 \%$.

Dye tunggal daun pandan, akar kunyit, black rice dan campurannya menjadi kandidat yang baik sebagai sensitiser yang ramah lingkungan dan biaya produksi rendah pada DSSC. 


\section{UCAPAN TERIMAKASIH}

Penulis mengucapkan terima kasih kepada Direktorat Penelitian dan Pengabdian kepada masyarakat, Direktorat Jendral Pendidikan Tinggi, Kementerian Pendidikan dan kebudayaan RI melalui DIPA (Daftar Isian Pelaksanaan Anggaran) Universitas Andalas No DIPA:023.04.1.673453/2015, atas bantuan pembiayaan pada penelitian Hibah Program Pascasarjana Unand 2015 ini.

\section{DAFTAR PUSTAKA}

1. Barnoy, E., Conley, M., Gan, S., Gefen, Y., Lovell, J., Mann, K., Shuchatowitz, A., Tobin, C., 2011, 'The potential of natural, photosynthetic pigments to improve the efficiency of dye-sensitized solar cells, PhD thesis, University of Maryland, Maryland.

2. Byung ,H.M., Youl, M.S., Chi, H.H, Titanium oxide Films Prepared by Sputtering, Sol Gel and Dip Coating Methods for Photovoltaic Application, Energy Procedia, 2013, Vol. 34: 589-596.

3. Cho, C.K., Chen, H.C., Kao, J,M., A study of Mixed Vegetable Dyes with Different Extraction Concentrations for Use as a Sensitizer forDye Sensitized Solar Cells, Hindawi Publishing Corporation International journal of Photoenergy, 2012, Vol. 10: 1155-1160.

4. Chunfeng, L., Yutao, C., Li, S., Xiao, L., Lan, H., Humin, C., Dechun, Z., Mixsolvent-thermal method for the synthesis of anatase nanocrystalline titaniumdioxide used in dye-sensitized solar cell, Solar Energy Materials \& Solar Cells, 2005, Vol.8: 457-465.

5. Dahlan, D. dan Fahyuan, H.D., Pengaruh beberapa Jenis Dye Organik terhadap Efisiensi Sel Surya Dye Sensitized Solar Cell, Jurnal Sains Materi Indonesia, 2014, Vol. 15, No.2,74-79.

6. Fahd, A.J., Amar, M., Fouad, A.W, Mohamed, A.A., ZnO Spin-Coating of TiO2 Photo-Electrodes to Enhance the Efficiency of Associated Dye-Sensitized Solar Cells, World Journal of Condensed Matter Physics, 2012, Vol. 2: 192-196.

7. Gratzel, M., Dye Sensitized Solar Cells, Journal of Photochemistry and Photobiology C, Photochemistry reviews, 2003, vol. 4: 145-153.

8. Kimpa, I.M., Momoh, M., Isah, U.K., Photoelectric Characterization of Dye sensitized Solar Cells Using Natural Dye from Pawpaw Leaf dan Flame Tree Flower as Sensitizers, Materials Sciences and Applications, 2012, Vol. 3: 281-286.

9. Lewis, N.S. dan Crabtree, G.W., Basic Research needs for solar energy utilization, report of united states department of energy office of Basic Energy Sciences Wokshop on solar Energy utilization(online), 2005, 1-260.

10. Maheswari, D. danVenkatachalam, P., Sol Gel Synthesis and Characterization of TiO2 Nano Films in the Building of DSSC, Journal of Electronics and Communication Engineering, 2013. Vol.4 : 29-33.

11. O'Regan, B., Graetzel, M., A low-cost, high-efficiency solar cell based on dyesensitized colloidal TiO2 films, Nature, 1991, 353(6346): 737-740.

12. Simon, M., Aswani, Y., Peng, G., Robin, H.B., Basile, F.E.C., Negar, A.A., Ivano, T., Ursula, R., Nazeeruddin, K., Gratzel, M., Dye-sensitized solar cells with 13\% efficiency achieved through the molecular engineering of porphyrin sensitizers, Nature Chemistry, 2014, Vol. 1861: 1-7. 
13. Valiulis, A.V. dan Silickas, P., Liquid phase deposition methods monitoring techniques influence for solid substrates and thin metal oxide films properties, Journal of Achievements in Materials and Manufacturing Engineering, 2007, Vol 24. PP. 188-192.

14. Zhou, H., Wu, L., Yurong, G., Tingli, M, Dye sensitized solar cell using 20 natural dyes as sensitizers, Journal of Photochemistry and Photobiology A: Chemistry, 2011, Vol. 219: 188-194. 